\title{
Religious Resurgence and International Relations Mainstream Theories: The Imperative for Theoretical Rethink and expansion
}

\author{
Chimaroke Mgba \\ Department of Political \& Administrative Studies, University of Port Harcourt, Nigeria \\ Email: marokemgba@yahoo.com \\ Wilfred I Ukpere \\ Department of Industrial Psychology \& People Management, Faculty of Management, \\ University of Johannesburg, South Africa \\ E-mail: wilfredisiomaukpere@gmail.com
}

\section{Doi:10.5901/mjss.2013.v4n14p535}

\section{Abstract}

This paper examines the implications of religious resurgence for international relations (IR). It argues that the rationalist character of IR mainstream theories makes them reluctant to factor in religion into the analysis of international relations but instead treat religion as being irrelevant in the conduct of state actors. However, the paper takes exception to this foundational position and avers inter alia that religion transcends the unobservable spiritual meaning to material reality with grave repercussions for the working of the international system and the foreign policy of states. The paper recommends a rethink and expansion of IR discipline to accommodate the ever visible impact of religion in international relations.

\section{Introduction}

In many ways the contemporary international system is in a state of flux and increasingly characterised by "transformation" (Webber and Smith 2002:15). New actors and images are not only emerging in their numbers and scope of activities, they are also having fundamental impact on the nature and character of the international system, as well as influencing the behaviour of state actors. Ever more visible in this context is the resurgence of religious actors in international relations. Haynes (2007:3) aptly admits that "a variety of religious actors are now involved in various significant ways in international relations". This scenario is aided and reinforced by globalisation that leaves the state increasingly battered (Migdal 1997:211), even as Smith (2007:1-12) observes that the main assumptions of the discipline are now challenged.

This paper attempts an examination of how mainstream theories of IR (realism/neorealism, liberal internationalism, and neo-Marxism) explain religion in contemporary international relations. The paper argues among others that following the history of the discipline and its commitment to rationalist ontology, mainstream theories are reluctant to factor in religion in their analysis, and therefore, treat religion as an unobservable and immaterial phenomenon. The paper however takes exception to this foundational view arguing that it is both conservative as it fails to acknowledge the obvious changes that are taking place in world politics, which is unscientific given that religious resurgence in contemporary world politics transcends the unobservable spiritual meaning and has become a material reality with serious implications for the nature and workings of the international system.

\section{Problem Statement}

As aforementioned, mainstream theories are reluctant to factor in religion in their analysis of international relations and therefore, treat religion as an unobservable and immaterial phenomenon.

\section{Research Question}

What are the implications of religious resurgence for international relations? 


\section{Objective of the Paper}

The main objective of the paper is to examine the implications of religious resurgence for international relations (IR).

\section{Outline of the Paper}

The paper begins with conceptualising religion to give it a material rather than a spiritual meaning. This is followed by a brief account of the history of the discipline and its commitment to rationalism that underlies its notion of secularization. Thereafter, the paper shall examine how mainstream IR theories explain religion and how this treatment is increasingly being challenged by the realities of religious resurgence. Finally, the paper concludes with a statement that IR mainstream theories need to shake off their conservative baggage and accommodate new developments in the international system, in order to be relevant in the $21^{\text {st }}$ century knowledge production. In short, IR requires a rethink and expansion.

\section{Theoretical Framework}

\subsection{Religion Defined}

It is instructive to make sense of what religion is or means here as a foundation to understanding what follows. Defining religion is problematic due largely to the elusiveness of the concept and the practices that go with its expression by different religious peoples and communities. In a sense, there are many definitions of religion as there are scholars. Hutchinson (1981) demonstrates this:

Formal definitions of religion are as numerous, as various, and often as mutually conflicting as there are students of religion. Often such definitions illustrate the oriental parable of the blind men describing the elephant each taking hold of part of the beast and defining the whole in terms of the part. Like the elephant, religion is a large and complex phenomenon.

James (1961:42) defines religion as "the feeling, acts, and experiences of individual men in their solitude, so far as they apprehend themselves to stand in relation to whatever they may consider the divine". Similarly, Kubalkova (2003:93) asserts that religion is "a system of rules (mainly instructive rules) and related practices which act to explain the meaning of existence, including identity, ideas about self and guiding behaviour of those who accept the validity of these rules on faith and internalise them". Both definitions share a common problem. However they reduce religion to forms of idea and identity that unite its adherents to seek for something celestial and beyond human reason.

Perhaps to make up for this limitation, Haynes (2003:455-456; 2004:8) offers both spiritual and material definitions of religion. Spiritually, he states that religion "pertains to models of social and individual behaviour that help believers to organise their every day lives". This notion of religion encompasses three ideas namely, transcendence (i.e. supernatural realities); sacredness (i.e. holiness); and ultimacy (i.e. eternity). This definition shares much in common with the ones mentioned earlier and have very little value for analytical explanation. However the second one by Haynes captures the material meaning of religion and provides the compass for explaining the social reality of religious resurgence in contemporary international relations. According to him, "religion in material sense encompasses religious organisations and institutions at least in part motivated by socio-political concerns". It refers to "religious establishments (i.e. institutions and officials) as well as socio-political groups and movements whose raisons d'être are to be found in religious concerns". Examples of these include Roman Catholic organisations, Opus Dei, Algeria's Reformist Front, the Church of England and its affiliates scattered across the world, Organisation of Islamic Conference, Pentecostal Fellowship of Nigeria, the Christian Association of Nigeria, India' Hindu, Eckankar Worldwide, etc. These organisations are not only concerned with spiritual matters of transcendence, sacredness and ultimacy, which falls under Berger's (1967) "Sacred Canopy", they are also bothered about terrestrial questions (i.e. material conditions) of day-to-day living. From the above context, religion is more than a spiritual and private experience. It is also a social reality capable of affecting and being affected by the world around it.

\subsection{International Relations and Rationalistic Ontology}

The history of international relations dates back to 1648 , following the Westphalia Treaty that established the notion of 
the nation-state with its sovereign and territorial components. The nation-state replaced the hierarchical religious order of the previous age. The Westphalia state system not only ushered in the idea of modern secular politics and the art of state-craft, it ended the religious wars of the old order. Thus, the politics of state-craft was liberated from the moral inhibitions and religious constraints of the medieval Christian world. The sovereign state now shaped the relations of the main political groupings of Europe, and those relations were now recognisable international relations (Jackson 1997:40). Consequently, religion began to decline as an organising social instrument, as the twin processes of modernisation and secularisation came to dominate human social engineering and organisation. These related concepts carried a shared assumption for international relations analysis, that is, sovereign states are now actors in international relations, characterised by attributes of sovereignty, non-intervention, territoriality, etc. (Haynes 2007:31).

The emergence of the nation-state as a formal political institution in the conduct of relations across national boundaries preceded the development of International Relations as an academic field. The discipline was established in 1919 following the devastation and ruins arising from the First World War. The war had raised grave concern among statesmen who were obsessed and desired to find explanations to the cause(s) of the war, in order to to safe coming generations from the scourge of wars. Stean and Pettiford (2005:1) explain:

The story of IR usually begins with the account of the great war (1914-1919), a war so horrific that many believed it was the war to end all wars. The destruction and devastation, the physical and economic effect...was a scale few could imagine before 1914. The study of IR grew out of the belief that war was the gravest problem facing humanity and that something must be done to ensure that there would be no more 'lost generations'.

Therefore, the focus of the discipline was limited almost exclusively on relations between nation-states and how to avoid war. This automatically reinforced the Westphalia state system- which is founded on the idea of secularism, implying the significant low influence of religion on social life (Haynes 2007:8). This idea not only separated religion from the state and confined it to the private domain; it also empowered and legitimized the state as the sole actor in international relations. Jackson (1997:40-41) further notes: "that secular move away from religious legitimacy has been the cornerstone of international society ever since. The treaties of Westphalia formally recognized the existence of separate sovereignties in one international society. Religion was no longer a legal ground for intervention or war among European states".

Interestingly, this was reinforced by Western European Enlightenment thinking rooted on rationalism. Rationalism is essentially a methodology constructed from the assumption that valid knowledge is based on gathering observable, empirical and measurable evidence subject to specific principles of reasoning. It proceeds from the idea that "existence is dependent on perception" (Hollis 1996). Rationalism is shaped by epistemological and methodological concerns that privilege quantitative methods, or attempt to qualify quantitative data. Rationalism has been useful and successful in knowledge production, it begins with a theory of individual and then utilises observation and hypothesis testing to substantiate, or falsify a set of claims relating to behaviour on the basis of this view (Keohane et al 1994). Knowledge is gained from sensory observation and is therefore rooted in inductive reasoning; facts exist independent of the observer and his/her values; and its goal is thus to build an objective empirical foundation for knowledge which produce testable and verifiable statements to explain, predict and attribute causality to events and processes in the world (Burnham el at 2008:31). It seeks to model political behaviour on the assumption that political actors are instrumental self-serving utility maximizers (Hay 2002:8). This has been at the centre of IR and Kurki and Wight (2007:14-15) underscore this point:

For a large part of the history of the field a particular conception of science has dominated. The influence of positivism as a philosophy of science has shaped not only how we theorize about the subject matter, and what counts as a valid question, but also what can count as valid forms of evidence and knowledge.

This accounts in most part, why religion is considered an irrelevant phenomenon deserving no much ink in the field. Religion is seen more as an abstract, private and unobservable phenomenon lacking the qualities of objective reality. The paper now turns to examining how mainstream IR theories explain religion.

\subsection{IR mainstream Theories and Religion}

The international relations mainstream is somewhat more complex and contested. It is partly as a consequence, rather more difficult to specify (Hay 2002:13). It is necessary at this juncture to focus on the core of the mainstream, namely realism/neorealism, liberal internationalism and neo-Marxism. 
Realism/neorealism is the oldest and most frequently adopted theory of international relations (Donnelly 2005:29). This is due in part to the history of the discipline, which almost exclusively focus on the state and the character of the international system. According to Gilpin (1986) human selfishness (egoism) and the absence of international government impose limitations on the international system, which require the primacy in all political life of power and security. Realism focuses mainly on the struggle for power, security and survival among states as the primary actors in an anarchic world. Indeed, "the struggle for power is universal in time and space and is an undeniable fact of experience" for both domestic and international politics (Morgenthau 1948). The lack of a centralised authority at the international level to bring states to a reasonable control underlines the centrality of anarchy and the general pattern of mistrust that characterise state behaviour. Mearsheimer $(2007: 75 ; 2001)$ clarifies:

In an anarchic system, where there is no ultimate arbiter, states that want to survive have little choice but to assume the worst about the intentions of other states and compete for power with them. This is the tragedy of great power politics.

This scenario is encapsulated in the notorious concept of "security dilemma". This intensifies balance of power politics and the subordination of all other issues to the security imperative. Haynes (2004:453) buttresses this point: "this is because the state is always the most important actor in $\mathrm{IR}$, and consequently any other form of international actor is, by definition subservient to the state ...the structure of the international system shapes the character of the political order". The international structure emerges from the interaction of states and thus constrains them from taking certain actions while propelling them towards others (Waltz 1991:29). Thus international relations, is narrowed to issues of power politics and religion does not equate with the calculus of power. States remain the main focus because they are rational actors seeking to maximise gains in relation to each other, employing reasonable means including cooperation when necessary to realise their specific goals defined in the context of national interests.

Realist/neorealist treatment of religion is in tandem with the rationalist assumption of objectivity and observability in social enquiry. Religion is seen as identity or part of culture lacking material or perceptible characteristics. As such it does not have implications on the security calculation of the state, nor constitute a regular pattern of human behaviour that can be explained. Realists are more impressed by the repeated occurrence of certain patterns across time than by the undeniable historical and cultural diversity of actors and interactions in international relations (Donnelly 2005:48). As a form of knowledge religion may be truthful but not useful in explaining the regularity in the pattern of state actions.

Realist treatment of religion is however simply naïve and in a certain way unscientific. It fails to acknowledge the effects religious identity and values have in the construction of state policies. Its assumption of a monolithic state with a common national interest negates the reality of "a multifarious body of primarily bureaucratic organisations and institutions" (Haynes 2004:454). The state is a body constantly factionalised and pulled in different directions by groups within and outside its territory. With reference to America Brian Schmidt (2008:9) argues that in the formation of state policies regarding Israel and her neighbours, non-governmental groups within the U.S society play significant role in shaping foreign policy. Mearsheimer and Walt (2006) corroborate this view in what is regarded in some quarters as a controversial piece:

Pro-Israel forces dominate in U.S think tank, which play an important role in shaping public debate as well as actual policy...pressure from Israel and the lobby was not the only factor behind the U.S decision to attack Iraq in March 2003, but it was a critical element.

Consequently, states can no longer be conceptualised as unified actors but are themselves multi-centric and subject to a variety of competing domestic and international pressures (Hay 2002:22). Similarly, realism has also proved limited in explaining the profound changes taking place in the international system that impact seriously on the territoriality/sovereignty of states, changes that emanate in some part from religious actors and organisations. The Roman Catholic Church's role in the anti-Communist revolution and democratisation in most of the developing world as perceived by Huntington's (1991) in his treatise "The third wave," has had far-reaching implications on the global system.

Similarly, in some Muslim states such as Saudi Arabia and Iran to mention but a few, religion constitutes an important and critical element in the formation of foreign policy. With specific reference to Iran, Sarioghalam (2001:1) argues that, "Iran's foreign policy is shaped, not mainly by international forces but a series of intense post-revolutionary debates inside Iran regarding religion, ideology and the necessity of engagement with the West and specifically the United States". Tehran also lends support to various Islamic radical organisations across the world as a way of challenging Western secular philosophy as well as spreading and preserving the Islamic doctrine.

Also, the terrorist attacks of 9/11 2001 in U.S, 3/3 2004 in Madrid, 7/7 2005 in London, etc masterminded by the al- 
Quaeda terrorist network have changed the whole character of global politics in ways unimaginable before now. American response was to change its military doctrine from that of Cold War deterrence to Bush's doctrine of a unilateral, preemptive war on terror, waged against individual acts of violence and linked to states wherever possible. In fact, many observers think that the entire system of states has been compromised and may be in the process of being superseded and therefore require explanations from realists.

\subsection{Liberal Internationalism and Relegion}

Liberal internationalism derives much of its assumptions from liberalism- a Western Enlightenment philosophy, that champions limited government, scientific rationalism, individual freedom from arbitrary state power, persecution and superstition (Donnelly 2005:55). Liberal internationalism is premised on the belief that political activities should be framed in terms of universal human condition rather than in relation to the particularities of any given nation (Stean and Pettiford 2005:22). It points to the growing importance of multinational corporations (MNCs), international non-governmental organisations (INGOs), transnational bodies, etc., as evidence that states are no longer the only significant actors in international relations. According to Haynes (2004:454):

The liberal internationalist paradigm begins from the premise that the state is not invariably the primary actor in IR. The recent growth and expansion of transnational relations underscores the significance of some kind of cross-border, nonstate actors.

Horrified by the brutality of war, the theory sought to build an institutional architecture of international mediation and mutual cooperation that might serve to guarantee perpetual peace (Hay 2002:17). It highlights the advantages of non-governmental and transnational relations between countries which encourage cooperation and solidarity across wide range of issues affecting humanity. Complex interdependence of nations (Keohane and Nye 1977; Keohane and Martin 1995) has become inevitable given the complex nature of both the contemporary globalised system and the massive problems associated with it (e.g. poverty, terrorism, global warming, proliferation of Weapons of Mass Destruction (WMD), refugee/displaced people, etc). It further assumes that territoriality and sovereignty of the nation-state have become anachronistic and no longer of any analytical value in explaining the character of the 'New World Order', hence the so called international institutions like the United Nations, World Bank, IMF, WTO, UNESCO, ICT, ICC to mention a few, have been set-up to address specific issues of international character.

The theory while acknowledging religious actors as one of the non-state transnational actors, insists that religion has limited influence on global outcomes. Religious bodies are not treated as serious contenders in international relations, but as private organisations engaged in identity issues and concerns that have very inconsequential impact on global outcomes. The reason for this argument is not difficult to discern. It derives more from the rationalist ontology of the theory itself and its commitment to the idea of secularism- separation of religion from the state. Interestingly, despite its pretension to the contrary, liberal internationalism still takes the nation-state as its reference point and to that extent retains traces of nationalism and statism in its analysis of international politics. This almost automatically magnifies the idea of states as interest maximising rational-actors. Liberal internationalists like realists/neorealists are at heart, rationalists, committed to a notion of states as rational actors carefully weighing up the respective merits and demerits of various courses of action in an attempt to maximise their utility (Hay 2002:18). Religion is therefore considered an idiosyncratic exercise which feeds on man's irrational impulse with limited material implications for the conduct of global relations.

This view is however limited in explaining the network of relations and influences in international relations. Its rationalist content tends as Hay (2002) puts it "to concentrate too heavily on political inputs in explaining outcomes, ignoring the key mediatory role of political institutions". Religious actors in today's world are pointedly more politically active and are engaged in activities that have transformatory effects on the conduct of state, its created bodies and its deployment of power. The Palestinian Liberation Organisation (PLO) with large Muslim membership does have influence in the shaping of policies by states and transnational organisations involved in the Middle East politics (Haynes 2007).

Also, since the early 1980s according to Weinberg et al (2002) most, but not all terrorist attacks have been by religious terrorist groups. And as Fox (2006:10) noted, many of these groups act internationally and include members from multiple states and the notable attacks like those of 9/11 2001 in the U.S. and the attack of March 11, 2004 in Madrid have considerable impact on the foreign policy of a number of states. Here, "radical religious ideologies have become vehicles for a variety of rebellions against authority that are linked with myriad of social, cultural and political grievances and challenge the Western established global order" (Juergensmeyer 2005). At another level, the Roman 
Catholic Church mentioned earlier, and the Organisation of Islamic Conference are religious organisations with transnational outlook and interests influencing global outcomes through the wielding of "soft power," namely ideational power (Haynes 2007:44-56, 136-151; Attina 1989). In this sense, in the last two decades beginning from the 1990s, religious actors from different faiths have become involved in both domestic and international attempts to resolve conflicts and build peace (Bouta et al (2005).

In sum, liberal internationalism's predisposition to routine and convention leads it more towards descriptive analysis of realities rather than explanatory interpretation, which unravels causal relationships in social investigation. In the contemporary world characterised by "The Clash of Civilisations" (Huntington 1993) religious ideas are veritable images in institutional decision-making processes that cannot be ignored. And liberal internationalism has failed to incorporate this reality in its explanation of international relations. This weakens its analytical potency and vitiates its conclusions.

\subsection{Neo-Marxism and Religion}

Neo-Marxist theory of international relations draws its roots from the timeless writings of Karl Marx and his later disciples, especially Lenin (1968). It is sometimes referred to as structural Marxism or scientific Marxism (Stean and Pettiford 2005:76). Marxism recognises the primacy of material things as opposed to idea and speaks so much about the transformation of material reality through a dialectical process of thesis, anti-thesis and synthesis. The general nature of dialectics which Marx developed from his critical examination of capitalism in Europe (Rupert 2007:149-156) is that, it is the science of interconnectivity. Its laws are abstracted from the history of nature and human society. It is these laws of material production that drove the capitalist man (bourgeois) in Europe into international production that created the world capitalist system, which is characterised by structural division between core, semi-peripheral and peripheral countries (Wallerstein 1974).

It was the contradictions generated by capitalist production including under-consumption and the poverty of the workers that led to capitalist expansion to non-European countries in search of raw materials, cheap labour and avenues for investments. Imperialism became both the process of counteracting the impediments to capitalist production and a means of creating capitalist system of domination and subordination. This is the world the European bourgeoisie created in its own image, which is a material and not an idealist/religious world.

The materialist conception of reality as laid down by Marx is what the neo-Marxist scholars adopted in explaining international relations. It is a world characterised by class struggle for control and domination of the social world of production. At the international level the dominant core capitalist countries and their powerful money classes are represented by bodies such as MNCs, IMF, World Bank, WTO, etc. These are the latest institutions in the neo-imperialist world of capitalist domination of weak, powerless and unindustrialised peripheral countries.

Following the principles and laws underlying its roots, neo-Marxism pays very little attention to religion which it sees more as a form of idea and an element of the superstructure. The theory emphasises the superiority of material things over ideas. Marx had argued that "It is not the consciousness of man that determines his social being, but on the contrary, it is man's social being that determines his consciousness". Social being represents the material world of production in the international system made up of the core, semi-peripheral and peripheral countries. Conversely, consciousness includes the spiritual and ideational world of man from where religion occupies a prime place. Religion in neo-Marxist terms is an unknowable and unobservable world devoid of any material essence. It is what Marx called "false consciousness" or the "opium of the masses"- an escape route from the material and objective world of reality to the spiritual. Thus to focus on religion in social analysis is to move away from the real world of class struggle and domination between countries and multilateral institutions that constitute it to an unreal and unscientific world.

Neo-Marxist conceptualisation of international relations like other mainstream theories borrows heavily from rationalist ontology. It claims that the world is material and knowable, and that man's knowledge of the world is based on experience and observation. That human reason can penetrate the internal nature of things and recognise their essence. This again falls short of acknowledging the influence and effects of ideas and identity on international social relations and the productive system deriving from it. It fails to capture the ever visible and observable materialist engagement of religion in contemporary world politics. The theory denies how the so-called "false consciousness" feeds into social and political structures and transforms them into religious images that influence state and multilateral decisions and policies. The challenges posed by increased religious fundamentalism which have pitched Islam against the West are global currents that can only be ignored at the expense of the 'New World Order'. As Tibi (2008:348-352) aptly demonstrates concerning religious extremism, "It is rather a powerful challenge to existing order of the international system of capitalist 
exploitation, subordination and oppression". Lechner (2008:349) reinforces the mobilisational character of religion in social engagement:

Religion in the contemporary world has become both a reaction to the deleterious effects of modernisation and globalisation, but a tool for socio-cultural identity.lt has become a global category, part of the global repertoire of collective action available to discontented groups, but also a symbol in a global discourse about the shape of the world...it represents a form of sociological realism rather than Western wishful thinking.

Religion aims at preserving traditional society from undue and unwelcome alien modernising influences and reforming society in line with religious teachings, morality, values norms and laws (Haynes 2001). According to DeGruchy (1995:5) religion actors now pursue public social justice issues and it is increasingly used as instrument for movements towards emancipation and emotional satisfaction (Tarrow 1998:112) in globalising the world with its accompanying communication and information network (Ahmed 1992:129). These are material questions which have raised serious challenge to the neo-Marxist treatment of religion as an unconscious and immaterial exercise in spirituality lacking any impact on the real world of material struggle.

\section{Research Design and Methodology}

The paper is a meta-analytical study, which relied on secondary sources of information. It is a qualitative study that is based on conceptual analysis, theory building and "emic" perspective (authors' viewpoint).

\section{Conclusion}

Religion has been an overlooked element of international relations. This is understandably so because IR as a social science discipline rejects it as a concrete phenomenon. The historical circumstances leading to the establishment of the field and its rationalist ontology have remained influential in the analysis of world politics. Mainstream IR theoretical assumptions tend to down play the role of emotion in social life and social structure in sociological and political analysis and places limited and almost exclusive focus on rationality (Harding 1986:85). They impose unnecessary delimitations of the subject matter of the discipline (Alker 1965).

This is both reductionist and conservative, and therefore fails to acknowledge the dynamic nature of human social structures as well as the role that religion plays in the whole dynamic process. It is no longer tenable and it amounts to naivety to overlook or treat as inconsequential the impact of religion in the contemporary nation-state system and its sovereign paraphernalia. For as Kubalkova (2006) cautions "if we in the field of international relations think that these pathologies, and the consequences of ignoring them, are the proper subject of some other field of inquiry, then we become irrelevant to modern society". Therefore, the rationalist ontology of the discipline and the conservatism that underlie it need to be transcended. Keohane (2002) a leading empiricist of the mainstream tradition admits this much and argues that it has become inevitable to go beyond the narrowness of the field and expand the scope of analysis to accommodate the new dynamics of the international system- including religious resurgence. It is time to rethink and expand the focus of the discipline. This is the call and challenge of a new age.

\section{References:}

Ahmed, A. (1992) Postmodernism and Islam: Predicament and Promise, Routledge, London.

Alker, H. Jr. (1965) Mathematics and Politics. The Macmillan Company, New York.

Attina, A. (1989) "The Study of International Relations in Italy", in H. Dyer and L. Mangasarian (eds.) The Study of International Relations: The State of the Art, Macmillan, Basingstoke, pp.344-57.

Berger, Peter (1967) The Sacred Canopy: Elements of a Sociological Theory of Religion. Garden City, Doubleday New York.

Bouta, T. et al (2005) Faith-Based Peace Building: Mapping and Analysis of Christian, Muslim and Multi-Faith Actors, Netherland Institute of International Relations, The Hague.

Burnham, Peter et al (2008) Research Methods in Politics, $2^{\text {nd }}$ edition. Palgrave Macmillan, New York.

De-Gruchy, J. (1995) Christianity and Democracy: A Theology For a Just World Order, Cambridge University Press, Cambridge.

Donnelly, Jack (2005) "Realism" in Scott Burchill et al Theories of International Relations. Palgrave Macmillan New York, pp.29-54.

Fox, Jonathan (2006) "The Multiple Impacts of Religion on International Relations: Perceptions and Realities", Politique etrangere, www.ifri.org/files/politique_etrangere/4_2006_Fox.pdf 
Gilpin, R. G (1986) "The Richness of the Tradition of Political Realism" in R. Keohane (ed.) Neo-Realism and Its Critics, New York. Harding, S. (1986) The Science Question in Feminism, Milton Keynes Open University Press.

Hay, Cox (2002) Political Analysis: A Critical Introduction. Palgrave Macmillan, Basingstoke.

Haynes, Jeffrey (2007) An Introduction to International Relations and Religion. Pearson Education Ltd., England.

Haynes, Jeffrey (2004) "Religion and International Relations: What are the Issues?" in International Politics, Palgrave Macmillan, No.41, pp.451-462.

Haynes, Jeffrey (2003) "Religion and Politics: What is the Impact of September 11?" in Contemporary Politics, Vol. 9, No.1, Carfax Publishing Taylor and Francis Ltd.

Haynes Jeffrey (2001) "Transnational Religious Actors and International Politics", Third World Quarterly, vol.22, No.2, pp.143-158.

Hollis, M. (1996) "The Lost Post"?" in S. Smith, K. Booth, and M. Zalewski (eds.) International Theory: Positivism and Beyond, Cambridge University Press, Cambridge.

Huntington, Samuel (1993) "The Clash of Civilisations", Foreign Affairs, 72(3), pp.22-49.

Huntington, Samuel (1991) The Third Wave: Democratisation in the Late Twentieth Century, Norman: University of Oklahoma Press.

Hutchinson, John (1981) Path of Faith. McGraw-Hill Book Company, New York.

Jackson, Robert (1997) "The Evolution of International Society" in John Baylis and Steve Smith (eds.) The Globalisation of World Politics: An Introduction to International Relations, Oxford University Press New York.

James, William (1961) The Variety of Religious Experience. Collier Books, New York.

Juergensmeyer, Mark (2005) "Religion in the New World Order", www.maxwell.syr.edu/moynihan/programs/sac/pape r\%20pdfs/marks\%20paper.pdf

Keohane, R. and Nye, J. (eds.) (1977) Power and Interdependence, Boston Little Brown.

Keohane, Robert (2002) "The Globalisation of Internal Violence, Theories of World Politics and the Liberation of Fear", in Power and Governance in Particularly Globalised World. Reutledge, New York.

Keohane, R. and Martin, L. (1995) "The Promise of Institutionalist Theory", International Security 20(1), Summer, pp.39-51.

Kubalkova, Vendulka (2006) "International Political Theology", in The Brown Journal of World Affairs, Winter/Spring vol. xii, issue 2 , pp.139-150.

Kubalkova, V. (2003) "Towards an International Political Theology", in F. Petito and P. Hatzopoulos Religion in International Relations: Return from Exile, Palgrave New York, pp.79-105.

Kurki, M. and Wight, Colin (2007) "International Relations and Social Science" in Tim Dunne et al (eds.) International Relations Theories: Discipline and Diversity. Oxford University Press Inc. New York, pp.13-33.

Lechner, Frank (2008) "Global Fundamentalism" in Frank Lechner and John Boli (eds.) The Globalisation Reader Third Edition, Blackwell Publishing Ltd., pp.348-352.

Lenin, V.I. (1968) Imperialism the Highest Stage of Capitalism, Moscow.

Mearsheimer, John (2007) "Structural Realism" in Tim Dunne et al (eds.) International Relations Theories: Discipline and Diversity. Oxford University Press Inc. New York, pp.71-88.

Mearsheimer, John (2001) The Tragedy of Great Power Politics. W.W. Norton: New York.

Migdal, J. (1997) "Studying the State", in M. Irving Lichbach and A. S. Zuckerman (eds.) Comparative Politics. Rationality, Culture and Structure, Cambridge University Press, Cambridge.

Morgenthau, Hans (1948) Politics Among Nations: The Struggle for Power and Peace, Alfred Knopf Inc., New York.

Rupert, Mark (2007) "Marxism and Critical Theory" in Tim Dunne et al (eds.) International Relations Theories: Discipline and Diversity. Oxford University Press Inc. New York, pp.148-165.

Sarioghalam, M. (2001) "Iran's Foreign Policy and US-Iranian Relations: A Summary of Remarks by Dr. Mahmood Sarioghalam, National University of Iran, at the Middle East Institute, February 5, 2001", www.209.196.144.55/html/b-sarioghalam.html

Schmidt, Brian (2008) "Theories of US Foreign Policy" in Michael Cox and Doug Stokes (eds.) US Foreign Policy, Oxford University Press New York.

Smith, Steve (2007) "Introduction: Diversity and Disciplinarity in International Relations Theory" in Tim Dunne et al (eds.) International Relations Theories: Discipline and Diversity. Oxford University Press Inc. New York, pp.1-12.

Stean, J. and Pettiford, L. (2005) Introduction to International Relations: Perspectives and Themes $2^{\text {nd }}$ edition. Pearson Education Ltd, England.

Tarrow, S. (1998) Power in Movement: Social Movements and Contentious Politics, 2nd Edition, Cambridge University Press, Cambridge.

Tibi, Bassam "The Challenge of Fundamentalism" in Frank Lechner and John Boli (eds.) The Globalisation Reader Third Edition, Blackwell Publishing Ltd., pp.358-363.

Wallerstein, Immanuel (1974) The Modern World System, Academic Press, New York.

Waltz, Kenneth (1991) "Realist Thought and Neo-Realist Theory" in R. Rothstein (ed.) The Evolution of Theory in International Relations: Essay in Honour of William T.R. Fox (Columbia).

Webber, M. and Smith, M. (eds.) (2002) Foreign Policy in a Transformed World, Pearson Education, Harlow.

Weinberg, L. et al (2002) "Characteristics of Terrorist Organisations 1910-2000", Presented at the 25 $5^{\text {th }}$ Annual Meeting of the International Society of Political Psychology in Berlin, Germany, July. 